\title{
SOME CHARACTERISTICS OF THE WESTERN PRAIRIE SOILS OF CANADA ${ }^{1}$.
}

\author{
BY FRANK T. SHUTT, M.A., F.I.C. \\ Chemist, Dominion Experimental Farms, Ottawa, Canada.
}

IT will be desirable, by way of preface, to say a word or two regarding the physical geography of the district, the soils of which form the subject of this paper.

\section{Physical Geography of the Great Plains Region in Canada.}

The term prairies as applied to the Canadian west is used to denote all that portion of the Great Plains Region north of the 49th parallel found within the confines of the three western provinces, Manitoba, Saskatchewan and Alberta, and northward to the Arctic Ocean. Commencing some fifty miles east of Winnipeg, at the western edge or rim of the Laurentian area, it extends westward to the foothills of the Rockies-though it must not be supposed that this immense stretch of country, some 800 miles if measured near the southern boundaries of these provinces, is one continuous, uninterrupted prairie or plain. It is rather a series of three great plains or plateaux, marked off by more or less distinct lines of escarpment which frequently take the form of ridges and wooded hills. Considering the region as a whole, it is found to narrow as we proceed northward, contracting to about 400 miles at the 56th parallel, and north of the 62nd parallel to still less, but further northward again expanding to its termination on the Arctic Ocean. It may therefore be considered as, in general, a huge wedge-shaped area extending northward and with its base lying along the Canadian frontier.

1 Read before the Agricultural Subsection of the British Association for the Advancement of Soience, Winnipeg, Aug. 27th, 1909.

Journ. of Agrio. Sci. II 
"The southern part of this great plain," wrote ${ }^{1}$ the late Dr Geo. M. Dawson twelve years ago, then Director of the Geological Survey of Canada, "is not only the most important from an economic point of view, but also that about which most is. known. It includes the wide prairie country of the Canadian west, with a spread of about 193,000 square miles of open grass land, an area more than twice that of Great Britain. Beyond the North Saskatchewan river, the plain becomes essentially a region of forest with occasional prairie tracts such as those of the Peace River Valley." Settlement began in the south of this prairie country and every year has seen successful grain growing pushed farther and farther to the north.

The first and lowest of the three steppes or prairie levels which constitute this interior plain is that of the Red River Valley with an elevation of about 800 feet above the sea. Its northern portion is occupied by the Winnipeg group of lakes, and to the south of Lake Winnipeg "it comprises some 7000 square miles of prairie land, which to the eye is absolutely flat, although rising uniformly to the east and west of the river. This is the former bed of the glacial 'Lake Agassiz,' the sediments of which constitute the richest wheat lands of Manitoba."

The second or middle prairie, with an average elevation of 1600 feet, extends from the escarpment forming the western boundary of the first prairie to a second fairly well marked and nearly parallel rise known as the Missouri Coteau. The first escarpment referred to comprises the so-called "Pembina Mountain" in the south and continues in a north-westerly direction including the Riding, Duck, Porcupine and Pasquia hills. The approximate area of this plain is given as 105,000 square miles, more than half of which is stated to be open prairie. It is less regular in its surface than the Red River Valley plateau, undulations, low hills and ridges being not uncommon. The soil is by no means as uniform in character as that of the first prairie, though large areas are of exceedingly fine quality and extremely fertile.

The third steppe, with an average elevation of 3000 feet, continues from the Missouri Coteau to the Rockies, and includes the western portion of Saskatchewan and Alberta south of the North Saskatchewan. Between the 49th and 54th parallels it has an area of about 134,000 square miles, open prairie land for the most part in its southern portion, but wooded towards its northern and north-western confines. Its topography is still more diversified than that of the second plain, due, according to Dr Dawson, to longer and more energetic action of the

1 Handbook of Canada, 1897. 
denuding forces of rain and rivers, both before and after the glacial period. The cbaracter of the soil is still more varied than that of the second steppe; while there is much that is fertile and good, areas of some magnitude exist which without special methods cannot be profitably farmed.

\section{Climatic conditions.}

Considered broadly, the summers are characterized by high day temperatures and an abundance of sunshine, the winters by clear, very cold weather. Usually spring advances very rapidly, for though the mean temperature in Manitoba during April and May may be in the neighbourhood of $35^{\circ}$, the daily maximum would be at least $10^{\circ}$ to $12^{\circ}$ higher. The annual precipitation over the whole area is comparatively light, but is somewhat greater for the first than for the second and third prairie levels. In a general way we might say that the rainfall becomes somewhat lighter as we proceed westward. The greater part of the rain over the district, however, falls during the growing season, and hence is particularly effective agriculturally. The distribution is, for the most part, well adapted to the production of the finest quality of wheat. Mr Stupart' remarks that the fact should not be lost sight of that although the total annual precipitation only averages 13.35 inches for the territories (now the provinces of Saskatchewan and Alberta) and 17.34 inches for Munitoba, the amounts falling between April 1st and October 1st are respectively 9.39 inches and 12.87 inches, or 70.3 and 74.2 per cent. of the whole. The average 12.87 inches in Manitoba is not far short of the average for Ontario during the same six months ${ }^{2}$.

Area suitable for farming.

It is estimated that there are in the three western provinces about $180,000,000$ acres suitable for cultivation, the greater part of which is adapted to wheat growing. Of this area probably not more than 6 per cent. is at present under cultivation. A further territory to the north of Alberta and Saskatchewan, within the boundaries of Mackenzie, Keewatin, Ungava, and Yukon, contains more than 900,000,000 acres, and it has already been shown that wheat can be successfully grown at several points within this immense area.

Western agricultural problems demanding Soil Analysis.

The types of soils in the prairie region, as might be supposed, are not so numerous as in Eastern Canada or British Columbia, but no

\footnotetext{
1 Direotor of the Canadian Meteorological Service. 2 Handbook of Canada, 1897.
} 
systematic, comprehensive laboratory examination has been made. The general high fertility of these soils has rendered unnecessary for the most part assistance from the chemist in their management. Only in certain specific cases have we made analysis of these soils, to ascertain if a district were affected with alkali, to learn if the failure reported were due to an insufficient rainfall or to poverty of the soil, and occasionally to furnish information regarding the character of the soil in some new district about to be opened up for settlement. From the soils so examined, probably some 200 samples, I have selected a few as representative of large, uniform areas of virgin, i.e. uncropped, unmanured land, together with one or two samples of cultivated soils.

Supplementary to the analytical work done with the view of ascertaining the amounts of total and available plant food present, we have studied to some extent the following questions relating to north-western agriculture : methods of culture as affecting conservation of soil moisture: nitrification and exhaustion of fertility through continuous grain growing: the effect of irrigation on the plant food content of the soil.

\section{Characteristics of Prairie Solls.}

\section{Humus and nitrogen content.}

The distinguishing characteristic of the western prairie soils is the large proportion of vegetable matter intimately incorporated with the sand and clay. To this they primarily owe their remarkable fertility and lasting quality. For the most part, they contain abundant stores of the mineral elements of plant food, but no more than many Canadian soils of less productiveness in other parts of the Dominion. But we have invariably found that soils of great productiveness are characterised by large percentages of organic matter and nitrogen, and, on the other hand, that worn, or partially exhausted soils, resulting from continuous grain growing or other irrational treatment, and soils from naturally poor areas, show meagre amounts of these constituents.

We have, further, noticed, as far as soils in humid and semi-humid districts are concerned, that there exists a relationship between the organic matter and the nitrogen-that methods of culture which increase the amount of the former raise the percentage of the latter, and on the other hand when the organic matter is destroyed, nitrogen is dissipated.

Functions of Humus. Humus is not only a storehouse for nitrogen that may be readily nitrified and made available for crop use; it also 
liberates during its decay goodly proportions of potash, phosphoric acid and lime. In all probability it furnishes a large part of the soil food supply of the growing crop.

Its influence on the physical condition of the soil is most markedly shown in increasing the capacity of the soil for holding moisture. Our investigations have shown that soils of the same type from adjoining areas, apparently under the same climatic conditions and with equal drainage, will retain moisture in proportion to the organic matter content. During the growing season prairie soils may retain amounts of water far in excess of those present in soils less rich in organic matter though favoured with a heavier precipitation-as in Eastern Canada. Further, the high absorptive capacity of these soils under suitable cultural methods allows moisture to be held over from one season to another, and thus it is possible in districts of scanty precipitation, by means of a fallow, to secure two good crops in three years when only very meagre yields would be obtained if the land were seeded every year. Humus also favourably modifies the tilth and temperature of both clays and sands.

Biologically, we have unfortunately no data to offer respecting these prairie soils except as to nitrification, but there can be but little doubt that a distinct relationship exists between the organic matter content and the bacterial life of the soil.

Nitrogen as an index of fertility. Our experimental work with soils in situ has assured us that of all the elements of plant food, nitrogen is the most potent in its influence on crop production. A high nitrogen content in soils of humid and semi-humid districts is invariably associated with a goodly proportion of humus-forming material and it is difficult to ascribe to each its own proper share in affecting the yield. But for prairie soils, whether clays or sandy loams, nitrogen may be regarded as the most reliable measure of their crop producing power. The extraordinary growth that characterises vegetation on the prairie as soon as the season opens is unquestionably due, for the most part, to the very rapid nitrification in the spring and early summer months consequent upon the large water content of the soil and the high temperatures which then prevail.

\section{Causes of fertility.}

The richness of these prairie soils lies in the tremendous accumulation of nitrogenous organic matter with its associated mineral constituents-the remains of countless generations of plant life and bacterial 
activity. Since the glacial period these prairies have been continuously clothed with grasses and leguminous herbage. The generally level character of the region has precluded those losses of soil by erosion which naturally occur in more or less mountainous districts.

Peculiarly favourable climatic conditions for soil enrichment have existed and still exist in the north-western provinces. High diurnal temperatures, long days, and a sufficient rainfall during the growing season are conducive to a most luxuriant growth. Rapid nitrification and conversion of inert mineral matter into available plant food take place practically throughout the summer-and, withal, there is no excess of rain to leach out and carry off the soluble constituents ${ }^{1}$. These conditions, further, tend to the production of more or less soluble mineral matter, alkaline in character, largely carbonate of lime, which renders the soil favourable for bacterial activity and vegetable life in general, and probably is of assistance in the formation and conservation of humus ${ }^{2}$. And lastly, we have the winter season with its intense cold practically locking up the stores of plant food from the autumn until the season again opens. Waste from leaching, such as occurs in countries in which the winter is mild and open, is thus prevented. This important fact has been, for the most part, overlooked by those who have written upon the various problems of western agriculture.

\section{Manitoban Soils.}

As illustrative of the soils of the first steppe-the prairie of the Red River Valley-we have tabulated the results from a few typical examples, restricting the data to the more important constituents. As already stated, the plateau south of the Winnipeg group of lakes is of remarkable uniformity and the data of soil No. 1 are representative of a very large area of the immediate valley of the Red River, though perhaps not typical in all details of the whole plateau. It is a deep, black clay

1 And here, perhaps, the opportunity best presents itself to say a word in reply to the question frequently asked as to the probable necessity of using superphosphate or other mineral fertilizers in the north-west. At present, at all events, there is no such necessity; over the larger portion of the prairie country, seasonal conditions undoubtedly to-day control the yields. As for the future, our work and observations lead us to believe that if the humus content of the soil is well maintained the day is far distant when there will be any need for phosphatic and potassio fertilizers.

2 In speaking of the invariably alkaline reaction of prairie soils, it may be remarked that their black colour-which undoubtedly is an important factor in their absorption of heat as soon as the season opens-results in all probability from the action of the alkaline compounds referred to on the organic matter and is not due to the presence of finely divided carbon from prairie fires as advanced by the late Dr Geo. M. Dawson. 
loam, of a fine and peculiarly characteristic granular structure. In the air-dried condition, it reduces easily to a greyish brown or greyish black powder. Though there is present a considerable amount of undecomposed root fibre, the soil proper presents a remarkable homogeneity in appearance, indicating a process of physical refining in its formation and a uniformity in chemical composition. The very large amount of organic matter present is undoubtedly intimately incorporated with the clay and sand which constitute the basis of the soil.

Though containing a large amount of clay, laboratory experiments show that this soil does not readily "puddle" on moistening, nor on subsequent drying does it form into a hard mass, but granulates on moderate pressure. The large amount of organic matter present has already been remarked; it exceeds 25 per cent. of the water-free soil. The nitrogen, calculated on the same basis, is found to be practically 1 per cent., from which it may be estimated that there is contained in an acre of soil to the depth of one foot from 20,000 to 25,000 pounds at least of this element. Since ordinary fertile soils to a like depth contain from 3500 to 10,000 pounds, the vast reserve of this valuable constituent in this prairie soil is apparent.

The soil is also very rich in potash, containing an amount $(1.033 \%)$ far in excess of that ordinarily met with in the fertile soils of Eastern Canada. Our data have indicated that good agricultural soils possess usually between 0.25 and 0.5 per cent. of potash.

Of phosphoric acid, it contains 0.29 per cent. This is slightly above the average, most of our good soils showing between 0.15 and 0.25 per cent.

The fairly large percentage of lime is worthy of note, since it indicates not only a fair supply for crop use but also a condition of the soil that should be particularly favourable to nitrification.

This prairie land, as regards the elements of fertility, ranks with the richest of known soils.

The late Dr Geo. M. Dawson wrote some years ago: "Of the alluvial prairie of the Red River much has already been said, and the uniform fertility of its soil cannot be exaggerated. The surface, for a depth of two to four feet, is a dark mould, composed of the same material as the subsoil, but mingled with much vegetable matter. Its dark colour is no doubt due in part to the general accumulation of the charred grasses left by the prairie fires. The soil may be said to be ready for the plough, and in turning the tough thick prairie sod, the first year a crop of potatoes may be put in, 
though it is not efficiently broken up till it has been subjected to a winter's frost. When the sod has rotted, the soil appears as a light, friable mould, easily worked and most favourable to agriculture. The marly alluvium underlying the vegetable mould, would in most countries be considered a soil of the best quality, and the fertility of the ground may, therefore, be considered as practically inexhaustible.

"The area of this lowest prairie has been approximately stated as 6900 square miles, but the whole is not at present suitable for agriculture. Small swamps are scattered pretty uniformly over its surface. The greater part of these swamps are, however, so situated as to be easily drained, either into the Red River or some of its tributaries, which are usually depressed 30 or 40 feet below the level of the surface."

Soils Nos. 2 and 3 are from Portage la Prairie, a district lying some 50 miles directly west of Winnipeg. It is one of the earliest settled localities in the north-west, and has long enjoyed a reputation for producing wheat of the very highest quality. In No. 2 we have an example of the virgin prairie-uncropped and unmanured; in No. 3, the same soil after 25 years of cultivation, in which grain growing was interspersed with fallowing to clean the land. The virgin soil shows more root fibre than the cropped soil and is somewhat darker in colour. Both might be described as black, friable loams, containing a considerable proportion of sand. The analytical data afford evidence of their richness in the elements of plant food, though they are not quite equal to the soil from the Red River Valley either in "total " or "available" constituents.

A comparison may be made of Nos. 2 and 3, since it is of much interest to learn what effect grain growing for a number of years may have had on the composition of the soil. A considerable reduction will be noticed in the percentages of organic matter and nitrogen in the cultivated soil due, as will be shown later, in a very large measure to fallowing-a system of immense value for the conservation of moisture and the destruction of weeds, but particularly wasteful of organic matter and nitrogen. In the mineral constituents no great differences are to be observed-the losses so far as they may be gauged by chemical analysis have not been at all excessive. This is not to be wondered at as the wheat crop does not remove large amounts of plant food in such a period as 25 years, representing say 16 crops.

Nos. 4 and 5 are composite samples from the Experimental Farm, 
Brandon, about 130 miles west of Winnipeg. They resulted from monthly collections (May to November) from plots under different cultural treatments in connection with moisture conservation experiments. In so far as physical character is concerned these two samples are practically identical, the soil being a mellow, black loam of a somewhat sandy type.

The tabulated data bear out their similarity in composition and we may regard them as typical and illustrative of the true prairie soil. We have only to remark the abundance of vegetable matter, the high nitrogen-content and the liberal supply of the mineral elements, and more particularly of potash and lime.

No. 6 is a soil from the district immediately west of Lake Dauphin and north-west of Lake Manitoba. The area is one that in parts is covered with willow and other "scrub," necessitating clearance before cultivation. This soil is probably to be regarded as representative of those lands inmediately surrounding the lakes and subject to more or less flooding during the early part of the season, for which drainage is of course necessary. It is a sandy loam, rich in organic matter, but with sufficient clay to render it somewhat refractory on drying. When drained it proves suitable for wheat growing, excellent returns having been obtained in favourable seasons.

Nos. 7 and 8 , the remaining two samples, are black, sandy loams from the Valley River, Dauphin district, collected in 1906 in an investigation to learn the influence of environment on the composition of wheat-a matter still under study in the Farm Laboratories. The richness of these loams in organic matter and their high nitrogencontent is worthy of remark. In potash, they are decidedly poorer than the stronger or more clayey soils of the north-west-indeed, in this constituent they are somewhat below the average found for Canadian soils of medium fertility. The percentages of "available" potash are similarly low, though not reaching the limit set by Dyer as indicating the need of a potassic fertilizer.

The amounts of phosphoric acid are considerably lower than in the prairie soil of the Red River Valley, but are about equal to those present in soils of average fertility. The large proportion of lime in these soils would undoubtedly favour rapid nitrification and also serve to render effective the somewhat sparse supply of phosphoric acid.

In the examples discussed two distinct types of Manitoban soils are represented, the heavy clay loam covering the true prairie region 
to the south of the province, and undoubtedly one of the finest wheat soils in the world, and the other representative of the sandy loams of the north-western and more humid area, more or less covered with small trees and sbrubs-a district regarding which we know less as to suitability for wheat growing, but nevertheless one which has produced profitable crops. Considered as a whole the quality of the wheat of this north-western section has not been equal to that of the southern and more distinctly prairie portion of the province, but there is evidence to support the view that the grain will improve in character with drainage and further cultivation of the soil.

Dr Russell has made mechanical analyses of the soils and reports on them as follows:-

Manitoban Soils.

\begin{tabular}{|c|c|c|c|c|c|c|}
\hline Locality .............. & Red River & Brandou & $\begin{array}{c}\text { Portage } \\
\text { la }\end{array}$ & $\begin{array}{c}\text { Portage } \\
\text { la } \\
\text { Prairie }\end{array}$ & Dauph & District \\
\hline Number of Sample........ & 1 & 4 & 2 & $\mathbf{3}$ & 7 & 8 \\
\hline Soil : & & & & & & \\
\hline Fine gravel ${ }^{1}$, above $1 \mathrm{~mm} .$. & - & - & - & - & - & - \\
\hline $\begin{array}{l}\text { Coarse sand, } 1 \text { to } 0.2 \mathrm{~mm} . . \\
\text { Fine saud, } 0.2 \text { to } 0.04 \mathrm{~mm} . .\end{array}$ & $\begin{array}{l}1 \cdot 6 \\
3 \cdot 8\end{array}$ & $\begin{array}{r}2 \cdot 5 \\
15 \cdot 4\end{array}$ & $\begin{array}{l}4 \cdot 3 \\
8 \cdot 6\end{array}$ & $\begin{array}{r}11 \cdot 4 \\
8 \cdot 4\end{array}$ & $\begin{array}{l}21 \cdot 1 \\
22 \cdot 6\end{array}$ & $\begin{array}{l}19 \cdot 5 \\
33 \cdot 3\end{array}$ \\
\hline Silt, 0.04 to $0.01 \mathrm{~mm} . \ldots \ldots \ldots$ & $17 \cdot 1$ & $17 \cdot 7$ & $30 \cdot 0$ & $29 \cdot 6$ & $10 \cdot 7$ & $11 \cdot 0$ \\
\hline Fine silt, 0.01 to $0.002 \mathrm{mu}$. & $\begin{array}{l}28 \cdot 2 \\
23 \cdot 3\end{array}$ & $16 \cdot 1$ & $15 \cdot 6$ & $14 \cdot 5$ & $6 \cdot 4$ & $6 \cdot 2$ \\
\hline Loss on ignition & $26 \cdot 3$ & $11 \cdot 3$ & $19 \cdot 4$ & $14 \cdot 8$ & $21 \cdot 5$ & $13 \cdot 1$ \\
\hline
\end{tabular}

"The Red River Valley soil shows the rather unusual feature of possessing more fine silt than clay; in mechanical composition it resembles the weald clay soils of Kent. But whilst the weald soils are difficult to work and are indeed commonly in pasture the Red River soil works very easily. The difference is due to the large amount of organic matter uniformly distributed throughout the soil and to the presence of a sufficient amount of lime. We have here an interesting case of a soil made workable by organic matter; so long as this does not fall too low the soil may be expected to maintain its fertility, but if continuous cereal cropping were persisted in too long without

1 As the soil had already gone through a $1 \mathrm{~mm}$. sieve the fine gravel could not be determined. 
replacing any organic matter the soil would become difficult to cultivate. The Brandon soil is somewhat similar.

"The Portage la Prairie soil closely resembles the good brick earths of the south-east of England. It is not dependent for its tilth on the organic matter; nevertheless the supply of organic matter should be kept up because it constitutes a rich source of nitrogenous plant food.

"The Dauphin District soils are very light and deficient in clay. Without their organic matter they would probably become like soils of similar mechanical composition elsewhere-lean, hungry sands, excellent for market gardening if well manured, but poor farming soils. Here, too, then we have a case where the mechanical structure of the soil is profoundly modified by the organic matter present."

\section{Saskatchewan Soils.}

In reviewing for the purposes of this paper the Saskatchewan soils examined by us during the past twenty years, a difficulty has been encountered in selecting only those truly representative of fairly large areas, since the second prairie steppe, comprising the larger part of this province, is not characterized by the uniformity noticed in the Red River Valley. This fact precludes the possibility of presenting here examples of all the types to be found, but it is worthy of remark, that the larger number of the soils examined-and more particularly those in the noted wheat-growing districts-have been found to be abundantly supplied with humus-forming material and nitrogen.

No. 1. A rich, black loam from Moosomin, a point on the main line of the C.P.R., 220 miles west of Winnipeg. The elevation of this locality is about $\mathbf{1 8 0 0}$ feet, and this soil may be regarded as fairly representative of the south-eastern part of the second prairie level. As in the types we have considered from the first steppe, this true prairie soil possesses abundant stores of plant food and is, judged by accepted standards, one of high fertility. It has not, however, looked at simply from the chemical point of view, a rank equal to that from the valley of the Red River.

No. 2. From the district of Tisdale, on the Canadian Northern Railway, about 160 miles due north of Indian Head. The district is in a large measure comparable with the Dauphin country already described, being partly wooded with scrub, poplar, \&c., and therefore, unlike the true prairie, requiring clearance. The soil is a greyish black 


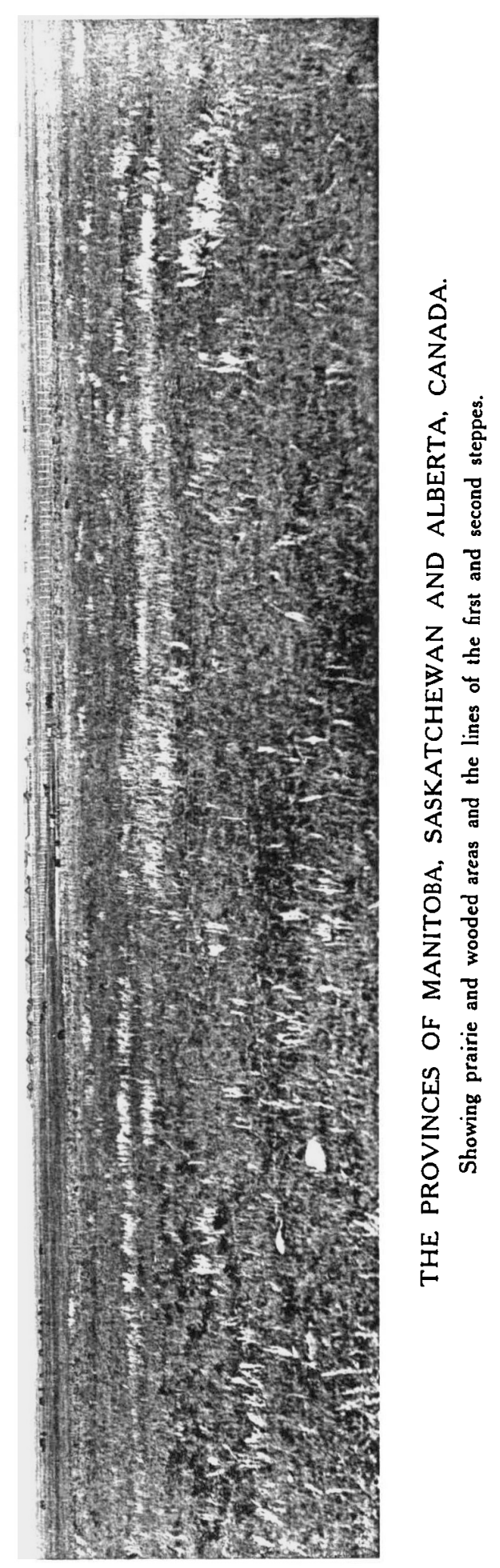


loam of a decidedly clayey nature, containing almost 0.5 per cent. of nitrogen, with notable amounts of potash and lime.

Nos. 3 and 4 are from Saltcoats and Yorkton, points on the northwestern branch of the C.P.R., 250 and 270 miles, respectively, west of Winnipeg, and approximately 75 miles north-east of Indian Head. Both are black, sandy loams of the true prairie type, rich in vegetable matter and nitrogen with excellent percentages of phosphoric acid and potash.

Nos. 5 and 6 are black loams of a markedly sandy character, taken from areas that had been under grain (without manure) for a period of about 15 years. Wolseley, the place of the collection, is about 20 miles east of Indian Head on the C.P.R. and has produced large crops of very fine wheat. These soils have borne probably ten crops of grain, with a bare fallow every third summer, but they are still of an exceedingly rich character, plentifully supplied with semi-decomposed vegetable matter and high in nitrogen-indeed as regards these constituents the data do not differentiate them from virgin prairie soils. They are decidedly above the average in "total," but not in "available" phosphoric acid.

Nos. 7 to 10 inclusive are from the Dominion Experimental Farm, Indian Head, and constitute a very instructive series, since they allow a comparison between the virgin paririe with the same soil after 22 years of cultivation, without manure. The soil would be designated as a heavy clay loam. A complete record of the cropping and fallowing since the prairie was broken in 1882 , shows that the "cultivated" soil had borne six crops of wheat, four of barley and three of oats, with a fallow between each crop since 1887, nine fallows in all. The virgin soil was taken from an adjacent area about 150 feet distant from where the cultivated soil had been taken. The samples were of a composite character and every precaution was taken to have them thoroughly representative. There is every reason to suppose that the soil, over the whole area examined, was originally of an extremely uniform nature; in other words, that at the outset the nitrogen-content was practically the same for the soils now designated as virgin and cultivated, respectively. The tabulated data show the percentage of organic matter and plant food in the first four and the first eight inches of these soils, and make very clear that enormous losses of organic matter and nitrogen have followed upon the present method of continuously cropping with grain. The particulars respecting the nitrogen are given in the following arrangement, which allows a ready comparison of the two soils in this important matter. 
Depletion of Soil Nitrogen.

Nitrogen-content of virgin and cultivated soils, Indian Head, Sask.

\begin{tabular}{|c|c|c|c|c|}
\hline & \multicolumn{2}{|c|}{ To a depth of 4 inches } & \multicolumn{2}{|c|}{ To a depth of 8 inches } \\
\hline & Per cent. & $\begin{array}{l}\text { Lbs. per } \\
\text { acre }\end{array}$ & Per cent. & $\begin{array}{l}\text { Lbs. per } \\
\text { acre }\end{array}$ \\
\hline 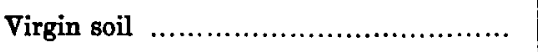 & $\cdot 409$ & 3824 & $\cdot 371$ & 6936 \\
\hline Cultivated soil & .259 & 2421 & .254 & 4750 \\
\hline $\left.\begin{array}{l}\text { Difference or loss due to removal in crops } \\
\text { and to cultural methods ........................ }\end{array}\right\}$ & $\cdot 150$ & 1403 & $\cdot 117$ & 2186 \\
\hline
\end{tabular}

Though the cultivated soil to-day, after nearly a quarter of a century's working, is still very rich and possibly might yield as fine a crop as it did at the outset, yet, compared with the untouched prairie, it is seen to have lost practically one-third of its nitrogen.

An enquiry as to what proportion of this loss is due to removal by crops and what to cultural operations shows that the nitrogen contained in the various grain crops grown in the 22 years amounted to approximately $700 \mathrm{lbs}$. per acre. If we subtract this amount from the total loss, calculated to a depth of 8 inches of soil, we shall see that the amount of nitrogen dissipated by methods of cultivation is more than twice as great as that removed in the crops. The loss ordinarily in the grain growing districts of the north-west would not be in all probability as great as that here recorded, because as a rule the land is fallowed every third year only. Nevertheless the deterioration must be marked, and, unless checked by the adoption of a system of rotation involving the formation of a sod, and the keeping of stock, will inevitably lead to that low productiveness which now characterizes large areas in eastern North America. A study of these partially exhausted areas both in Canada and in the north-eastern States makes it clear that the deterioration has been due, in a very large measure, to the loss of humus and the dissipation of nitrogen consequent upon growing grain and potatoes without any due return of organic matter.

A marked falling off in phosphoric acid is also to be noted, though what is perhaps of more significance is the reduction in the proportion of this element in the available condition. Since loss of phosphoric acid cannot be accounted for save in removal by crops, it 
Frank T. Shutu

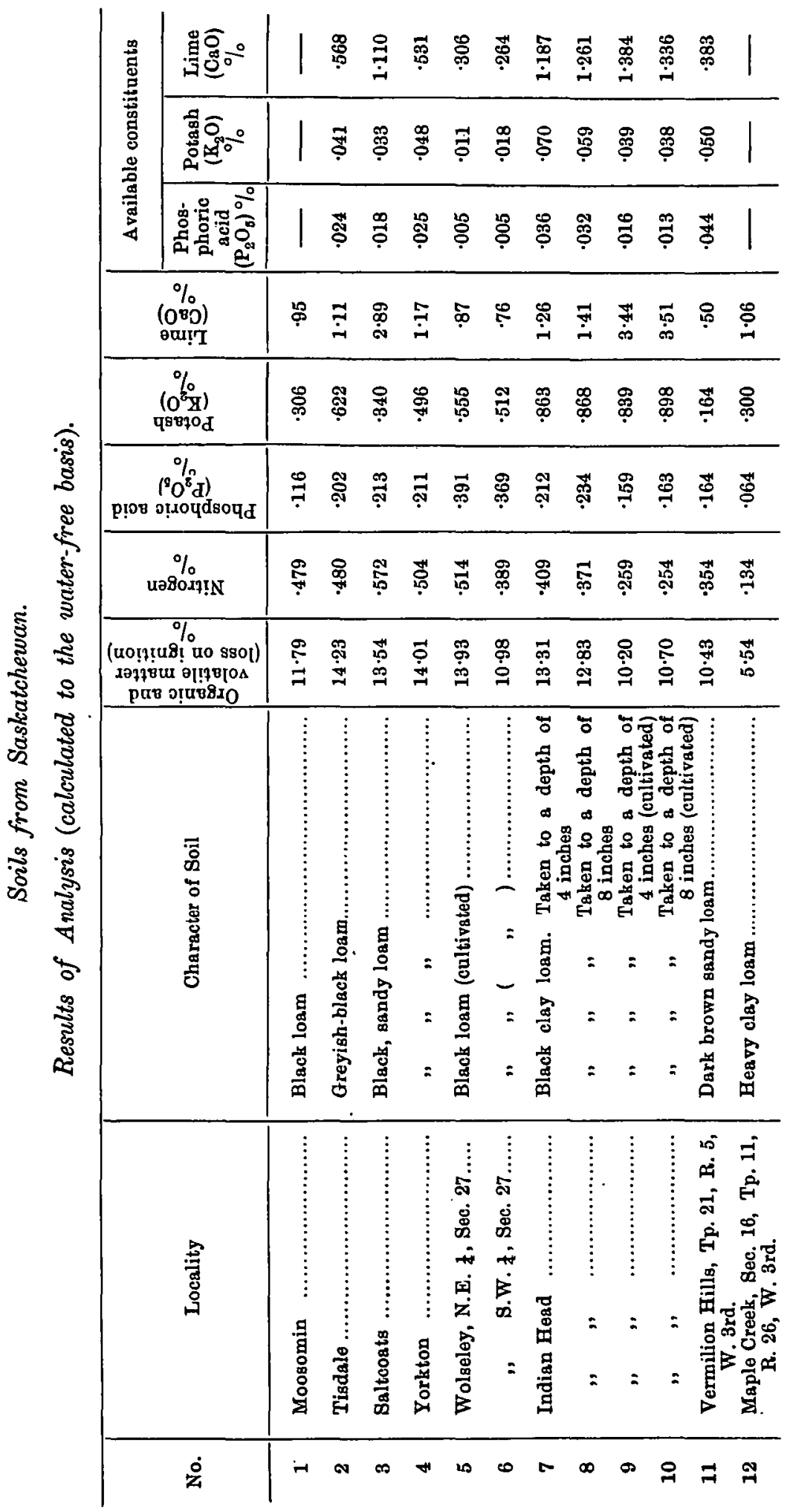


would seem that in continuous grain growing the rate of abstraction exceeds that of conversion.

In the "total" potash the differences throughout the series are not large, but, as in the case of phosphoric acid we find that the percentage "available" in the cultivated soil is considerably less than in that of the prairie'.

No. 11 from the prairie in the neighbourhood of Vermilion Hills, 130 miles west of Indian Head and some 20 miles north of Lake Chaplin. It is a dark-brown, sandy loam. In organic matter and nitrogen it is fully the equal of the heavier (clay) loams of the prairie, but as regards phosphoric acid, potash and lime, it is, as might be expected, somewhat inferior. Although the "total" stores of this mineral plant food may not be very large it is significant that the "assimilable" proportions are not less than in those heavier loams which are considered wheat soils par excellence.

Dr Russell has made mechanical analyses of the soils and reports on them as follows :-

Saskatchewan Soils.

\begin{tabular}{|c|c|c|c|c|}
\hline Locality....................... & Wolseley & Tisdale & \multicolumn{2}{|c|}{ Indian Head } \\
\hline Number of Sample.............. & 5 & 2 & 8 & $a^{2}$ \\
\hline 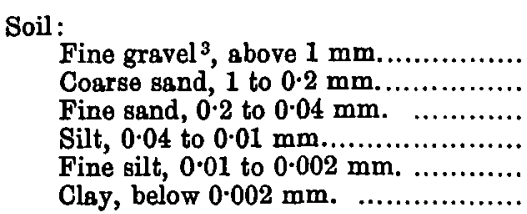 & $\begin{array}{r}16 \cdot 7 \\
14 \cdot 8 \\
27 \cdot 7 \\
8 \cdot 1 \\
15 \cdot 1\end{array}$ & $\begin{array}{r}\overline{0.9} \\
24 \cdot 1 \\
20 \cdot 5 \\
13.7 \\
21.3\end{array}$ & $\begin{array}{l}\overline{10 \cdot 4} \\
13 \cdot 7 \\
15 \cdot 3 \\
11 \cdot 9 \\
27 \cdot 2\end{array}$ & $\begin{array}{r}\overline{10 \cdot 2} \\
9 \cdot 9 \\
15 \cdot 3 \\
11 \cdot 1 \\
33 \cdot 9\end{array}$ \\
\hline 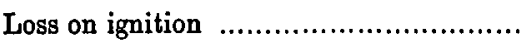 & $13 \cdot 9$ & $14 \cdot 2$ & $12 \cdot 8$ & $16 \cdot 8$ \\
\hline
\end{tabular}

"The Wolseley soil shows a remarkably uniform distribution of the various grades of particles. In its general structure it resembles the Portage la Prairie soil, and the remarks made on p. 346 apply here also.

1 There is at times a certain loss of surface loam in the older cultivated areas by drifting, and this in some cases would affect the phosphoric acid and potash content, and more especially that portion which is available.

2 A composite sample not dealt with in the trble of chemical analysis.

3 As the soil had already gone through a $1 \mathrm{~mm}$. sieve the fine gravel could not be determined. 
"The Tisdale soil owes its clay-like nature partly to the absence of coarse sand and partly to the rather large quantity of clay present. It contains no mineral material capable of keeping it open and friable, but its abundance of organic matter serves this purpose instead.

"The Indian Head soil contains a large amount of clay which, however, is tempered by the presence of 10 per cent. of coarse sand. It would still be rather intractable were it not so well supplied with organic matter and lime."

No. 12 is from an area in the eastern part of the third steppe, 281 miles west of Indian Head along the main line of the C.P.R. and not far from the boundary between Saskatchewan and Alberta.

The district from which this soil was taken enjoys as a rule but a very limited rainfall and, previous to the adoption of special methods for the conservation of moisture, gave but scanty yields. It was thought by some that the poor crops were due to a deficiency in some important fertilizing constituent, or to the presence of "alkali" or other matter deleterious to plant growth. Analysis shows that there is no lack of plant food, though the percentages of organic matter and nitrogen are only about one half of those found in the richer prairie soils. Absence of "alkali" was established, and the conclusion reached that the meagre yields were due to insufficient moisture rather than to any inherent fault in the soils.

\section{Albertan Soils.}

No. 1. This soil, a black, sandy loam, was collected in the neighbourhood of Tilley, a point on the main line of the C.P.R. about 50 miles west of Medicine Hat, a district that owing to sparse rainfall bas hitherto been considered better adapted to ranching than to grain growing. As in the case of the two immediately preceding examples this soil was supposed to be deficient in some particular or to contain alkali. The data, however, show that there is an abundance of plant food present and an entire absence of alkali. Improved methods of culture, resulting in the better conservation of soil moisture, have shown that the poor yields were not due to the poverty of the soil, but to insufficient water supply.

No. 2, from the Dominion Experimental Farm at Lethbridge, an important centre in Southern Alberta, a true prairie region, where until recently ranching has been the chief branch of agriculture. Irrigation is desirable, if not indeed necessary, but in many seasons fairly good yields can be obtained by the adoption of proper cultural methods for 
the conservation of soil moisture. The soil appears to be extremely uniform in character and very productive provided there is a sufficiency of moisture.

The sample, taken in this case to a depth of 12 inches, is a dark grey, inclining to black, sandy loam, light and friable, free from stones and containing an abundance of root fibres. Though not as rich in organic matter and nitrogen as the majority of the prairie soils hitherto considered, the results are quite satisfactory, especially when the greater depth to which this sample was taken is considered. In mineral constituents it seems to be fairly well supplied, the amounts being such as are possessed by many soils of high productiveness.

No. 3 was collected from an uncultivated area on a bench in the valley of the Elbow River, some few miles from Calgary. The soil of the district is stated to be "well fitted for either cultivation or grazing." It might be classed as a light to medium, black, prairie loam, especially rich in organic matter. It is practically neutral and is well supplied with plant food.

Soils 4 and 5 were taken at no very great distance from No. 3 and are in appearance very similar to it. They were examined to learn what effect irrigation might have on the stores of fertility. No. 4 is from a non-irrigated area while No. 5 is from irrigated land, collected 50 feet from the lower side of an irrigation ditch and 100 feet from No. 4.

Undoubtedly the feature of greatest interest in the comparison of the data is the decidedly higher percentages of soluble (available) mineral constituents in the irrigated soil, and it is important to note that, while the non-irrigated land is neutral, the irrigated soil is slightly alkaline. These features are not uncommon and two possible causes for them may be advanced. The first is the deposition of mineral salts from the irrigation water and the second-probably the chief cause-is the bringing up of these compounds from the lower strata by increased capillarity induced by greater surface evaporation consequent upon irrigation.

It may be said that as Southern Alberta is of the true prairie character, so Northern Alberta is largely wooded, enjoying a more liberal rainfall and is naturally a country better adapted to mixed farming. The soils of Northern Alberta are for the most part characterized by high percentages of organic matter and nitrogen and in this

1 In all instances, unless otherwise specified, the soil collections were made to a depth of 9 inches. 
Frank T. Shutt

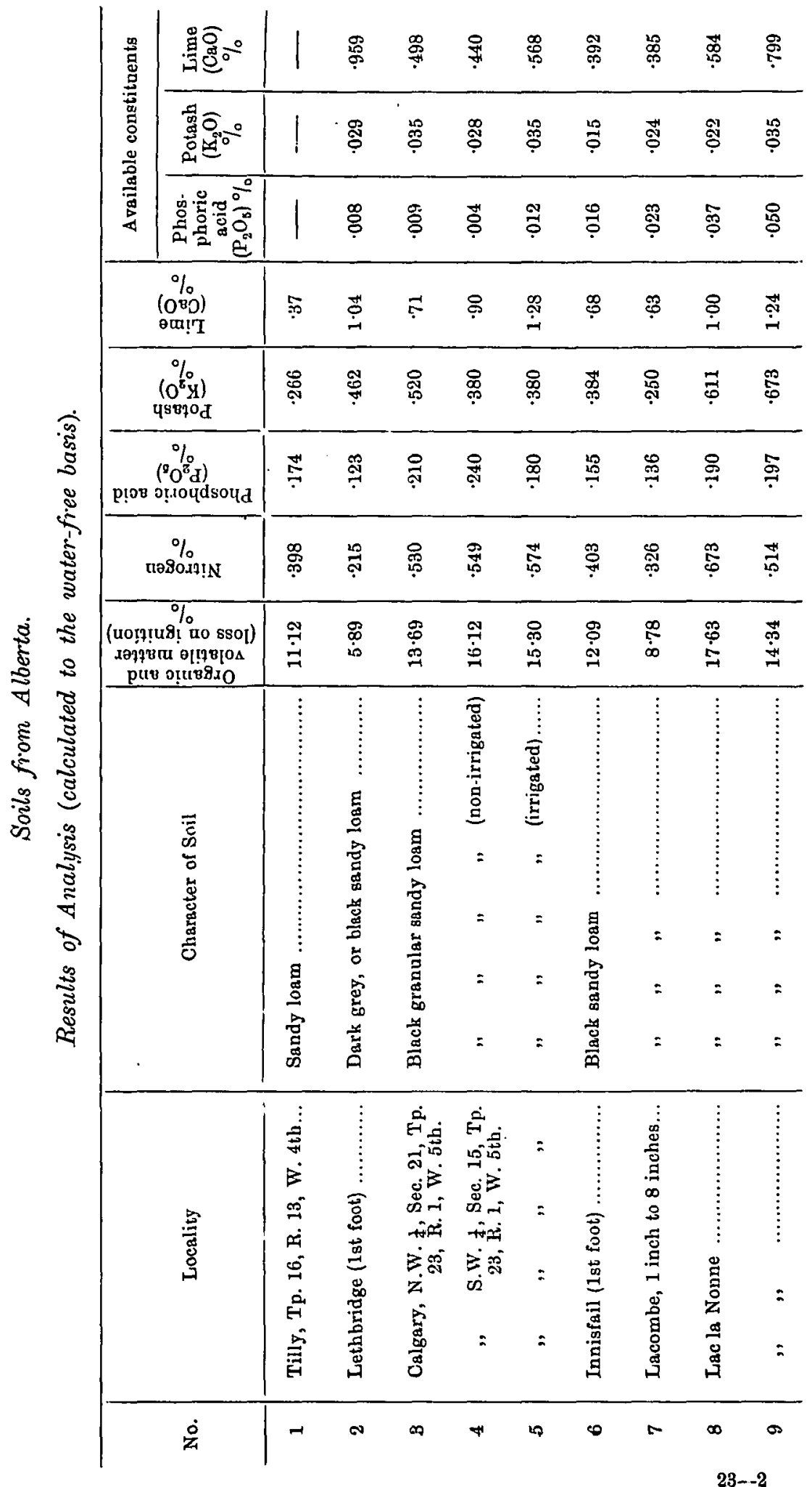


respect are somewhat superior to those in the southern part of the province. We have in this a certain confirmation of the view that a relationship exists between rainfall and the organic content of the soil.

The samples so far considered from this province have been representative of areas in Southern Alberta, the remaining examples are from points north of Calgary.

No. 6 is from Innisfail, an excellent district for dairying and mixed farming, some 80 miles north of Calgary on the Edmonton branch of the C.P.R. This sample had been collected to a depth of 12 inches. As received, in the air-dried condition, it was a loose, friable, greyish black, sandy loam, full of fibre and evidently rich in organic matter.

No. 7 is fairly representative of the soil on the recently acquired Dominion Experimental Farm at Lacombe, a point some 40 miles north of Innisfail. The country and soil in this neighbourhood are similar in character to those of the Innisfail district, just described, and indeed may be considered typical of a very large part of this northern portion of the province.

Nos. 8 and 9 are clay loams from Lac la Nonne, a district lying some 40 miles north-west of Edmonton. These loams are very similar, containing a large proportion of clay and organic matter; they are greyish black in colour when air-dried. They are rich in nitrogen, above the average in potash and lime, and are fairly well supplied with phosphoric acid. Under proper cultural operations and favourable climatic conditions, they should prove to be highly productive soils.

Dr Russell has made mechanical analyses of the soils and reports on them as follows:-

Alberta Soils.

\begin{tabular}{|c|c|c|c|c|}
\hline Locality....................... & \begin{tabular}{|} 
Lethbridge \\
(1st foot)
\end{tabular} & Calgary & Innisfail & $\begin{array}{l}\text { Lac la } \\
\text { Nonne }\end{array}$ \\
\hline Number of Sample............... & 2 & 3 & 6 & 9 \\
\hline 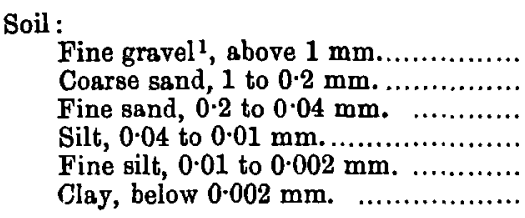 & $\begin{array}{l}\overline{22 \cdot 4} \\
25 \cdot 0 \\
11 \cdot 3 \\
11 \cdot 0 \\
17 \cdot 0\end{array}$ & $\begin{array}{r}\overline{8 \cdot 5} \\
26 \cdot 7 \\
17 \cdot 1 \\
11 \cdot 4 \\
17 \cdot 0\end{array}$ & $\begin{array}{r}\overline{6.5} \\
16.4 \\
32.0 \\
10.0 \\
15.3\end{array}$ & $\begin{array}{r}\overline{0 \cdot 1} \\
10.6 \\
20.5 \\
21.8 \\
24.6\end{array}$ \\
\hline Loss on ignition & $5 \cdot 9$ & $13 \cdot 7$ & $12 \cdot 1$ & 14.3 \\
\hline
\end{tabular}

1 As the soil had already gone through a $1 \mathrm{~mm}$. sieve the fine gravel could not be determined. 
"The soils are all well supplied with the fine particles that hold water near the surface for the crop, and are therefore adapted to the dry conditions in which they occur. The Lethbridge soil contains sufficient coarse sand to render cultivation easy. On the other hand, the Lac la Nonne soil is almost devoid of this constituent and depends for its workability on the organic matter present. The Calgary and Innisfail soils have the structure of good loams, and, like the Portage la Prairie soil on p. 346, are not dependent for their tilth on the organic matter, although they derive much plant food from this source."

\section{Conservation of Soil Moisture.}

It will be evident from the facts brought forward in this paper that while it is advisable to adopt such a system of farming as will lead to the maintenance of fertility, the necessity of returning plant food in manures and fertilizers will not be generally felt for some time to come, so rich is the soil of the prairies over very large areas. But while, as yet, nitrogen (or any other element of fertility) cannot be regarded as the limiting factor, the amount of soil moisture available during the growing season does most markedly affect the yield. We consequently find that the important question of prairie farming, and more particularly in districts of sparse rainfall, is the conservation of moisture for the crop's needs.

Fallowing is the general means adopted to this end. This comprises the preparation by deep ploughing of a reservirir, so to speak, for the stornge of the rainfall in the soil, and the formation by frequent cultivation of a dry earth mulch to check evaporation. To ascertain the extent to which water may be carried over by fallowing from one season to another, a series of experiments was conducted some years ago on the Experimental Farms at Brandon and Indian Head, in which the amounts of moisture were determined to depths of 8 and 16 inches, respectively, on soils fallowed and cropped the previous season ${ }^{1}$. It was shown that at Brandon the soil which had been fallowed contained during May, June and July - the months of growth-amounts varying from 330 to 65 tons per acre, to a depth of 16 inches, over and above those in the soil that had borne a crop. Similarly at Indian Head the excess of moisture in the land that had been fallowed varied from 175 to 160 tons. While the amounts of moisture so conserved must depend upon the character of the season and the thoroughness with which the fallowing is carried out, the evidence furnished by this investigation is sufficient

1 The data of this investigation will be found in the Report of the Chemist, Dominion Experimental Farms, 1900. 
to show the great value of this practice as a means of storing up moisture for the crop of the succeeding year'.

\section{Notes on the Agriculture of the Pralries.}

Manitoba. Grain growing has been and will probably remain the most importaut feature in this province and more especially in the Red River Valley proper. However, recent years have witnessed a change. More and more stock is being kept and the tendency of the future will be largely towards smaller holdings and mixed, i.e. diversified farming. Dairying and the production of beef, mutton and pork are already extensively prosecuted with profit in many sections. Grass, roots and all classes of forage crops can be grown successfully. Of the cereals, wheat is the staple, but oats, barley and flax are also largely sown.

The soils as we have seen are varied in character, from heavy clays in the Red River Valley to sandy loams in the nortbern parts, but all are richly endowed with vegetable matter and plant food, more particularly nitrogen. Many of these soils have now been cropped for 25 and 30 years and as yet without any apparent falling off in productiveness. In this province the rainfall is usually sufficient for the needs of the crop, more particularly if special methods for its conservation are followed.

Saskatchewan. Considering the province as a whole, the characterizing feature, as in Manitoba, is grain growing, chiefly wheat. There are however certain fairly well defined areas, each with its own more or less special adaptation to some particular branch of agriculture. Thus, for instance, in the western part cattle ranching on the large scale has been for many years the principal industry. A considerable proportion of the northern half of the province is as yet unsurveyed, but from such facts as have been gained, it will prove most suited to mixed farming.

As the province becomes more thickly settled the one-crop system (grain and fallow) is giving place to more rational methods and diversified farming is becoming more and more popular.

\footnotetext{
1 Unfortunately, fallowing is not without its concomitant evils. Wo have already pointed out that dissipation of humus and nitrogen results from continuous grain growing and that the greater part of this loss is more particularly consequeut upon the stirring and opening np of the soil by repeated cultivation during the fallow season. It must now be stated that a further loss may result from fallowing; viz. the removal of more or less of the rich surface soil by erosion and drifting. The constant cultivation of the land breaks up the fibre-the binding element which gives the toughness to the prairie sod. As the fibre becomes shorter the surface loam more readily dries and pulverizes; it is then easily carried away by the strong winds which prevail at certain seasons in prairie regions. Very serious losses have occurred from this cause in some of the older cultivated districts of the north-west. The adoption of a cropping system in which the soil is occasionally put in sod suggests itself as the natural and best corrective.
} 


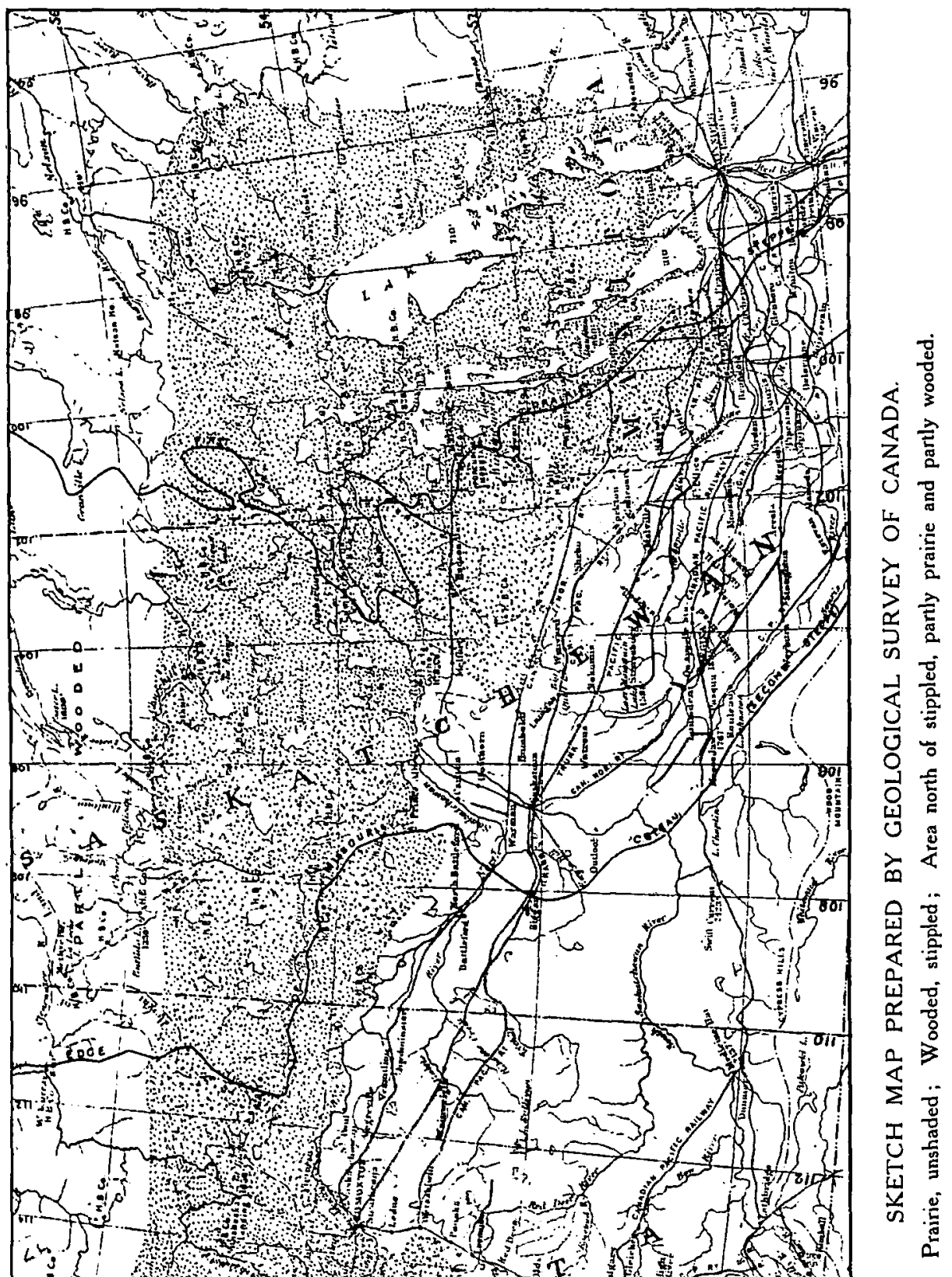


Soils of several types are to be found, and wheat of excellent quality is apparently produced, alike on clay and sandy loams, provided climatic conditions are favourable.

It is as yet too early to notice any effect on the soil in the grain growing districts from the one-crop system, but as pointed out there is a marked destruction of the organic matter and dissipation of the nitrogen where such a plan is followed, and this eventually will injuriously affect the soil both chemically and physically.

Alberta. The world-wide reputation of Alberta as a typical ranching country has been well earned, though it is more particularly in the southern part of the province that this branch of agriculture has been followed. In more recent years the growing of winter wheat has in certain districts of the south largely displaced the raising and grazing of stock. Northern Alberta is more particularly adapted to mixed farming and for some years past, on the lines of railway, co-operative dairying has been profitably prosecuted.

Southern Alberta may be considered a semi-arid country and one therefore in which provision for irrigation is desirable. Mention may therefore be made of the extensive irrigation scheme of the Canadian Pacific Railway, by which about eleven hundred thousand acres immediately east of Calgary will eventually be watered. A survey of this territory by the writer, in 1906, showed some variation in the character of its soils, though like all true prairie areas, uniformity was the prevailing feature, the characteristic soil being a moderately heavy black loam from four to eight inches in depth, with a subsoil of chocolate coloured clay. The whole area appears to be one well adapted to diversified farming.

In concluding this review, we may be allowed again to emphasize the general uniformity of the prairie soils, their richness in plant food, more especially in nitrogen, and their favourable physical condition due, chiefly, to the large proportion of semi-decomposed vegetable matter they contain. Further, though the rainfall over a large portion of the prairies is not a generous one, as judged by Eastern standards, good yields may be obtained by fallowing, even in very dry districts. And lastly, the climatic conditions usually prevailing in the prairie country are such as to bring about a rapid conversion of the stores of plant food into available forms without undue waste, and to favour a luxuriant growth and early ripening of the crop.

The writer desires to record his thanks to Dr E. J. Russell, Goldsmith Chemist, Rothamsted Experiment Station, who, in addition to the work involved in making the mechanical analysis, has very kindly expressed his appreciation of the soils from the physical data. 